Original Research

\title{
Heavy Metals and Arsenic Soil Contamination Resulting from Wastewater Sludge Urban Landfill Disposal
}

\author{
Andrey Mikhailovich Dregulo, ${ }^{1,2}$, , Nicolai Gennadievich Bobylev ${ }^{1}$ \\ ${ }^{1}$ Federal State Budgetary Educational Institution of Higher Education Saint-Petersburg State University, \\ 7-9 Universitetskaya emb., 199034, Saint- Petersburg, Russia \\ ${ }^{2}$ Scientific Research Center for Ecological Safety of the Russian Academy of Sciences, \\ 18 Korpusnaya Str. 197110, Saint- Petersburg, Russia
}

Received: 6 December 2019

Accepted: 3 May 2020

\begin{abstract}
The purpose of the study is to assess the soil contamination of a sewage sludge landfill, bordering specially protected natural areas. The content of heavy metals and arsenic in the landfill soil was assessed based on national soil quality standards in terms of monitoring landfills for priority pollutants $(\mathrm{Cd}, \mathrm{Cu}, \mathrm{Pb}, \mathrm{Zn}, \mathrm{Ni}, \mathrm{As})$, and in comparison with background concentrations for sod-podzolic soils in the European part of Russia. Soil samples were taken at 9 observation points from depths of 5-20 cm. The concentrations of heavy metals and arsenic were studied through mass spectrometry with ionization in inductively coupled argon plasma and atomic absorption spectrometry. The results of the study showed a significant increase in $\mathrm{Cd}, \mathrm{Cu}, \mathrm{Ni}, \mathrm{Pb}$, and $\mathrm{Zn}$ in 2017 compared to 2011. The concentrations of $\mathrm{As}$ decreased slightly, but the concentration range remained stable. The concentrations of heavy metals and arsenic had the following maximum range: $\mathrm{Cd}_{1083}>\mathrm{Cu}_{45}>\mathrm{Pb}_{16}>\mathrm{Zn}_{5}>\mathrm{Ni}_{4}>\mathrm{As}_{3}$ in comparison with background concentrations of these elements in the European part of Russia. In general, the degree of the landfill soil contamination can be described as dangerous and very dangerous according to national soil quality standards.
\end{abstract}

Keywords: landfill sludge, soil degradation, heavy metals, environmental damage

\section{Introduction}

Heavy metals, as the most common pollutants in sewage sludge, can be identified as the leading limiting factor determining the direction and nature of the biogeocenoses development. A significant part of

*e-mail: adregulo@bk.ru; a.dregulo@spbu.ru heavy metals is included in soil-forming processes and absorbed by vegetation [1].

Leaching and migration of heavy metals in the soil are caused by differences of soils that cannot inactivate the leaching of heavy metals to different degrees, which makes it difficult to choose the soil that could be most suitable for normalization purposes [2].

With a radial distribution of heavy metals, the highest concentrations can be concentrated in the upper 
horizon of 0-5 cm, for example, for $\mathrm{Pb}-6.5 \mathrm{LOC}, \mathrm{Cu}-5$ LOC, NI and Co concentrations increase slightly with depth. Higher concentrations of labile CR and $\mathrm{Mn}$ compounds are also observed in the upper horizon [3].

However, many heavy metal compounds are highly labile and can migrate to a significant depth in the soil. For example, leaching of heavy metals from waste reached a depth of 50-100 $\mathrm{m}$ at landfills in Nigeria [4].

Complex biogeochemical conditions created in the process of waste compaction $(\mathrm{pH}$, humidity, anaerobic conditions Red/Ox potential) mediate the occurrence of intermediate but highly toxic forms of heavy metals, such as methylmercury. Toxic mercury compounds of methylmercury were detected in the ranges of $0.4-12.4 \mathrm{mg} / \mathrm{kg}$ and $0.1-27.0 \mathrm{mg} / \mathrm{kg}$ [5] at landfills in China.

The difference in approaches and selection of methods to sewage sludge disposal is due to the specific physical and chemical composition of the sludge components $[6,7]$, which cannot be destroyed (as well as heavy metals), which largely causes the problem.

According to the data [8] for 1999, treatment facilities in Russian cities annually produce more than 100 million $\mathrm{m}^{3}$ of sewage sludge with a humidity of $98 \%$ or more than 2 million tons of dry matter. At the same time, sewage sludge utilization reaches up to half of the total volume of $16-63 \%$ in the most of developed countries, which is disposed of at landfills, the second largest part of the resulting sludge is disposed of in agriculture by $23-60 \%$, about $16-35 \%$ is burned, $5-24 \%$ is dumped into the sea. It is expected that the dynamics of sludge formation will increase annually [9].

According to some estimates, more than 10 tons of sewage sludge (dry matter) is generated in the EU countries and an increase of up to $50 \%$ of the present volume is predicted [10].

According to the data [11], 584,242.4 tons of sewage sludge were not removed from sewage treatment facilities in Russia in 2015, which corresponds to $10.42 \%$ of the total sludge formed in the country.

In the period of 2006-2015, a significant proportion of newly formed sewage sludge was not disposed of annually in Russia, reaching from $7.26 \%$ to $38.10 \%$ of the total share. The exact amount of sewage sludge not disposed of in a centralized way is unknown [12].

In 2003, each EU member state had to develop a national strategy for reducing biodegradable waste. In the final version of waste disposal, it is envisaged that the only economically viable option will be heat treatment with subsequent placement of ash in landfills.

In 2005, Sweden adopted a new law prohibiting the silt dumping. Since then, there are five main applications of silt that are used nowadays: fertilizers, construction soil, coating material, energy production by means of combustion, and biogas production. In the EU and the US, special standards for the content of dangerous chemicals and petroleum hydrocarbons in soils and groundwater are used [13].

In Russia, maximum permissible concentrations of heavy metals and arsenic are not differentiated geographically; soil types and soil stability are not taken into account.

In the context of all the above mentioned, it is highly probable that much of the risk from long-term exposure to sewage sludge on the soil in each case is undetermined and possibly exceptional. Therefore, the purpose of this study is to assess the soil contamination of a landfill with a long cycle of sewage sludge disposal.

\section{Material and Methods}

The object of research is "Severny" sewage sludge landfill, located in the urban agglomeration of St. Petersburg $\left(60^{\circ} 4.714 .30^{\circ} 9.808\right)$ (Fig. 1). The landfill is located in the Northern part of St. Petersburg on the

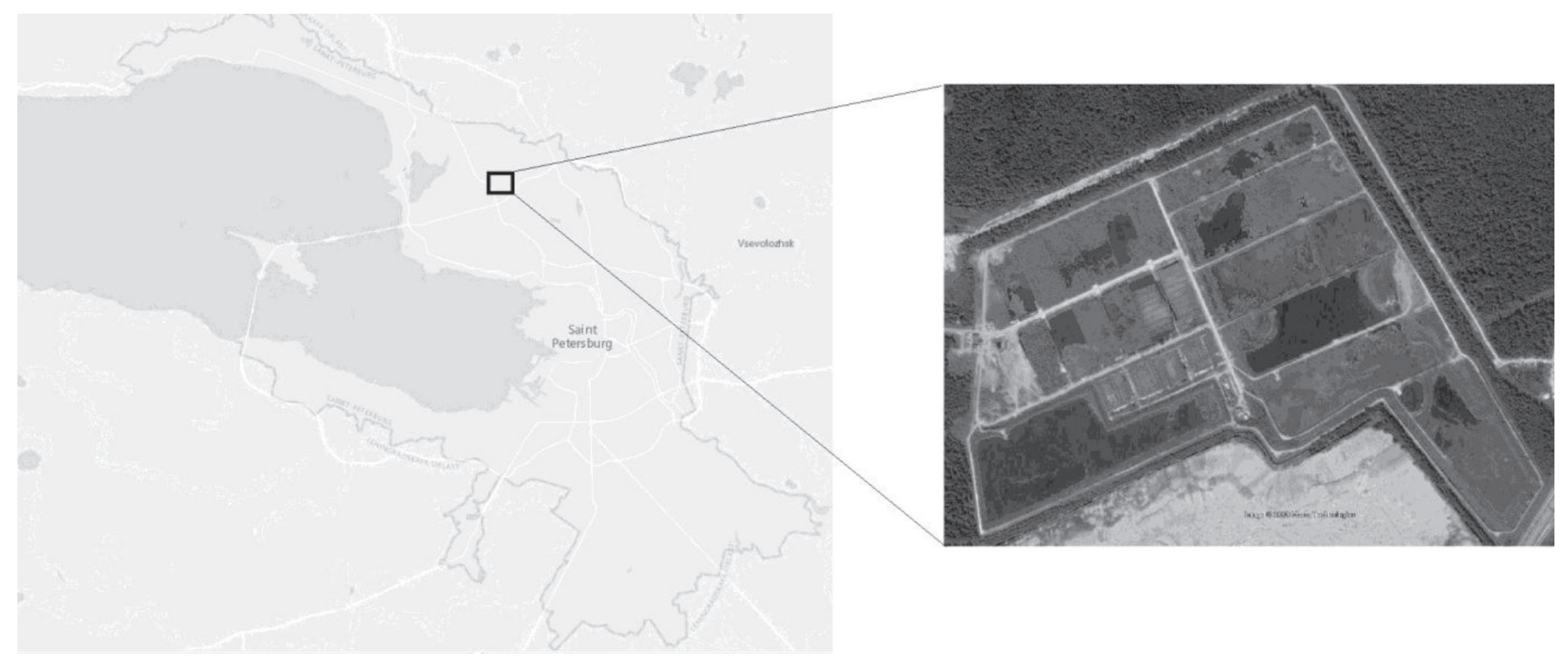

Fig. 1. Location of the landfill of sewage sludge. 


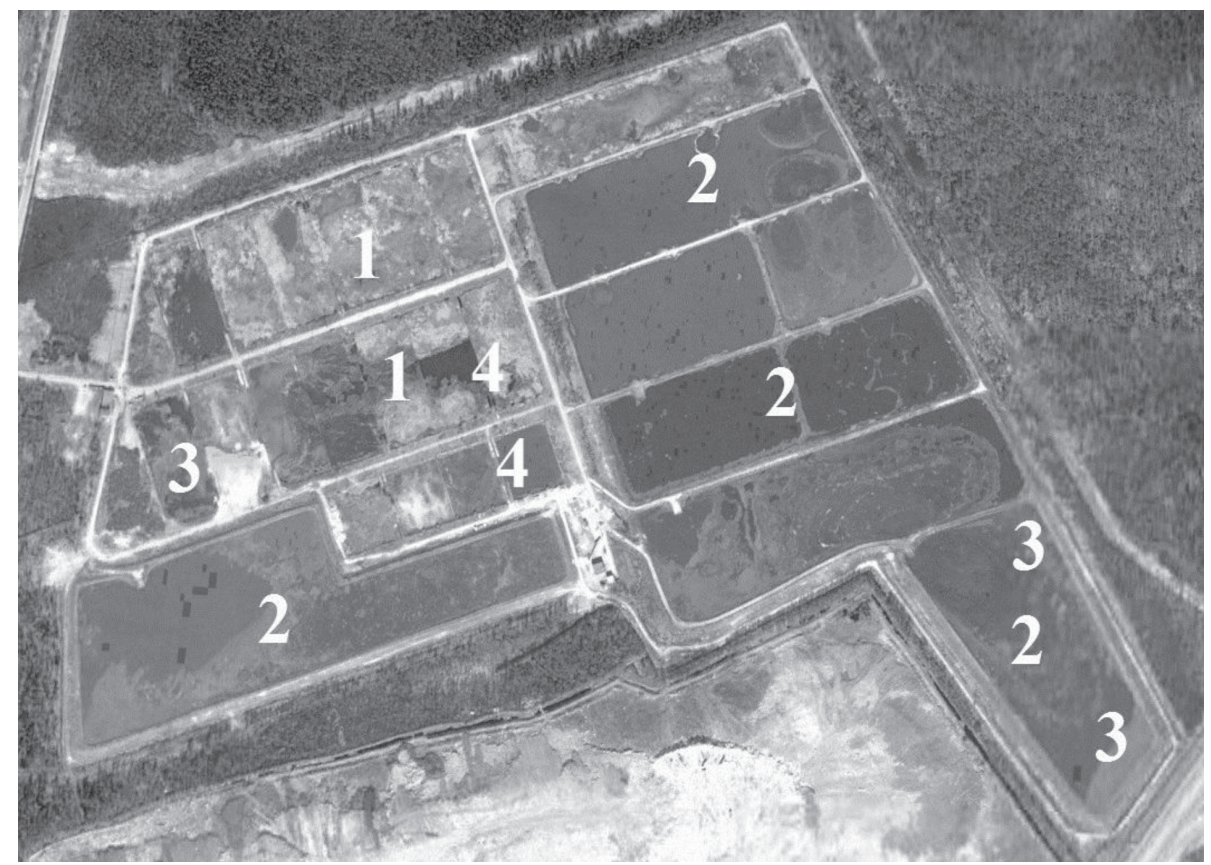

Fig. 2. Disposal of waste water sludge on the landfill. 1 -“Old" drying beds (utilization of sewage sludge in the period from 1984-2003). 2) - utilization of sewage sludge in the period from 2003-2007). 3) -Sewage sludge ash is the by-product produced during the combustion of dewatered sewage sludge in an incinerator (in the period after 2007 to the present). 4 - Sites for geotubes (from 2004-2007).

border with the Leningrad region in the catchment basin of the Eastern part of the Gulf of Finland. The area of the landfill is 83 hectares. The landfill "Severny" was chosen as an indicator due to its "atypical" functional use compared to similar objects. Its atypicality is caused by the fact that until the decision was made to use this territory as a landfill for the "disposal" of sewage sludge, there were drying beds on these territories from the beginning of the $50 \mathrm{~s}$ of the last century, which subsequently lost their functional purpose of "processing" sewage sludge and were used to "deposit" sewage sludge. The sewage sludge treated on drying beds was used for agricultural purposes.

The landfill itself has been functioning since 1984 . The landfill disposed of sewage sludge of various processing types, including fresh untreated sludge, sludge treated in geotubes and ash from the combustion of sewage sludge (Fig. 2). All this makes this landfill "atypical" for Russian practice, which the authors of this study could explore.

In the future, with the increase in the population of St. Petersburg, the expansion of urban areas and the development of the industrial complex, sewage sludge became unsuitable for its utilization for agricultural purposes, so a decision was taken to increase the territory for the preparation of landfill infrastructure.

The landfill annually exported about 200 thousand $\mathrm{m}^{3}$ of unstable sludge. By the early 1990s, the landfill was about $70 \%$ full. While maintaining the dynamics of the sewage sludge disposal, the free areas of the landfill could have already been filled by the beginning of the 2000s [15]. Untreated sewage sludge (up to 2003), sewage sludge treated in geotubes, and ash from incineration of sewage sludge (from 2007 to the present) were deposited on drying beds and slime accumulators. Since 2007, the landfill has disposed of ash from the incineration of sewage sludge.

Soil sampling was carried out at 9 observation points located around the landfill perimeter. Samples were taken from a landfill from a depth of $5-20 \mathrm{~cm}$. The sampling points are shown in (Fig. 3.)

The concentrations of heavy metals and arsenic were studied by means of mass spectrometry with ionization in inductively coupled argon plasma and atomic

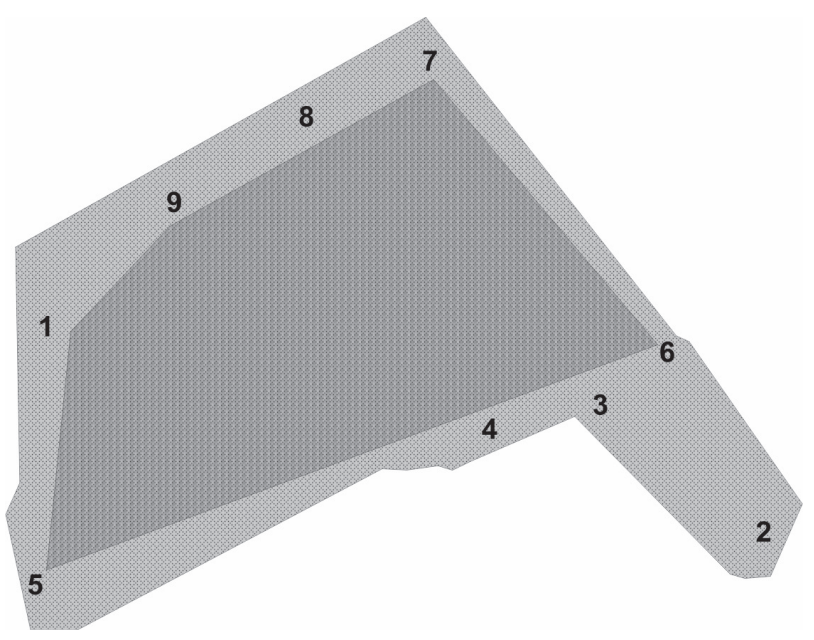

Fig. 3. Soil sampling points in the testing ground body.

WWW - Zone of the most polluted soils of the testing ground (symbol). 
Table 1. Comparison of the heavy metal content in the sewege sludge deposited at the "Severny" landfill.

\begin{tabular}{|c|c|c|}
\hline \multirow{2}{*}{ Heavy metals } & \multicolumn{2}{|c|}{ Concentration $\mathrm{mg} / \mathrm{kg}$} \\
\cline { 2 - 3 } & Year 2011 & Year 2017 \\
\hline $\mathrm{Cd}$ & - & 4.5 \\
\hline $\mathrm{Co}$ & 13 & 4.1 \\
\hline $\mathrm{Mn}$ & - & 750 \\
\hline $\mathrm{Cu}$ & 24 & 380 \\
\hline $\mathrm{Ni}$ & 8.9 & 34 \\
\hline $\mathrm{Hg}$ & - & 0.56 \\
\hline $\mathrm{Cr}$ & 85 & 76 \\
\hline $\mathrm{Zn}$ & 777 & 570 \\
\hline
\end{tabular}

absorption spectrometry $(\mathrm{P}<0.05)$. The SPSS Statistics 22 software package was used for statistical processing of the results obtained. Satellite images of the polygon were obtained by using ArcMap 10.4.1, Surfer 13, and Grapher 11.

\section{Results and Discussion}

The analysis of the heavy metals content in the landfill soil in different years (studies in 2011 and 2017) (Table 1) showed a slight decrease in the concentrations of $\mathrm{Co}, \mathrm{Cr}$ and $\mathrm{Zn}$ and a significant excess of $\mathrm{Ni}, \mathrm{Cu}$. Studies of long-term dynamics of changes in heavy metal concentrations show a largely fluctuating nature of the heavy metals content in the landfill soils. However, it should be noted that the LOC limits for $\mathrm{Ni}, \mathrm{Cu}$ are lower than for $\mathrm{Co}, \mathrm{Cr}$ and $\mathrm{Zn}$, which means that the potential hazard may increase despite such variability in the concentration ranges of $\mathrm{Co}, \mathrm{Cr}$ and $\mathrm{Zn}$ (Fig. 4).

A significant increase in concentrations of heavy metals and arsenic was observed at the sites no. 1, 5, 6, 7,9 . These sites were originally drying beds. Relatively low concentrations of heavy metals and arsenic were found at points 2, 3, and 4, probably because the sludge storage at this site was completed more than 15 years ago between 1986-2003. These structures are almost completely overgrown with grass and bushes (Fig. 5).

This fact is consistent with other studies showing that even after 15 years of sludge storage at the landfill, metals are transferred from sewage sludge to the environment [16].

Most heavy metals in soil and plant systems are in the form of cations and tend to form a hydroxide sludge with an increased $\mathrm{pH}$ level [17]. It should be taken into account that the effect of $\mathrm{pH}$ on metal complexation can be changed by the competition of $\mathrm{H}^{+}$and metal ions on organic $\mathrm{COO}^{-}, \mathrm{OH}-$ and $\mathrm{C}=\mathrm{O}$ or inorganic matter [18-20],

With an increase in soil $\mathrm{pH}$, the increasing electronegativity of these groups increases their
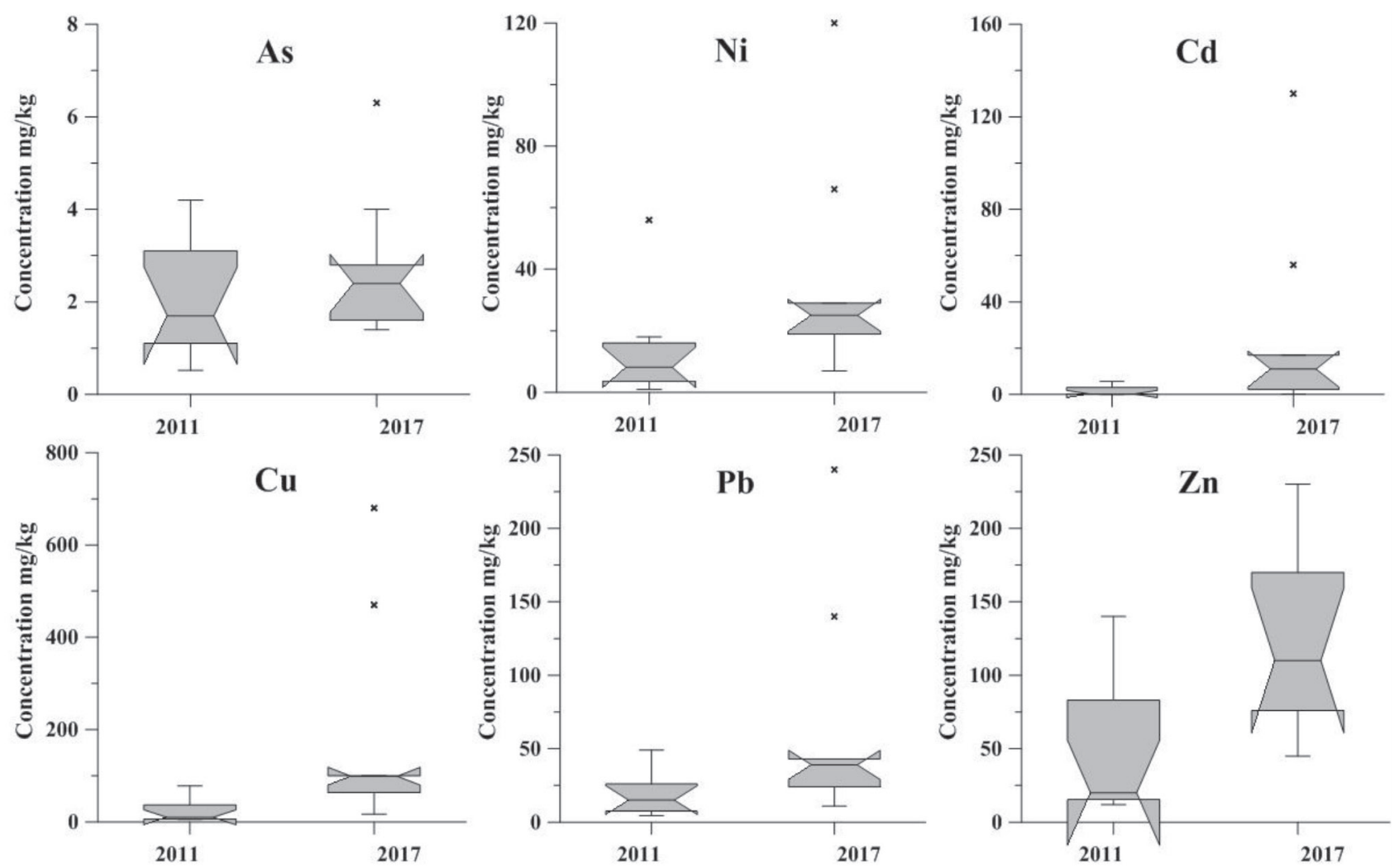

Fig. 4. Long-term dynamics of changing in heavy metalls and arsenic concentrations in the testing ground soil. 

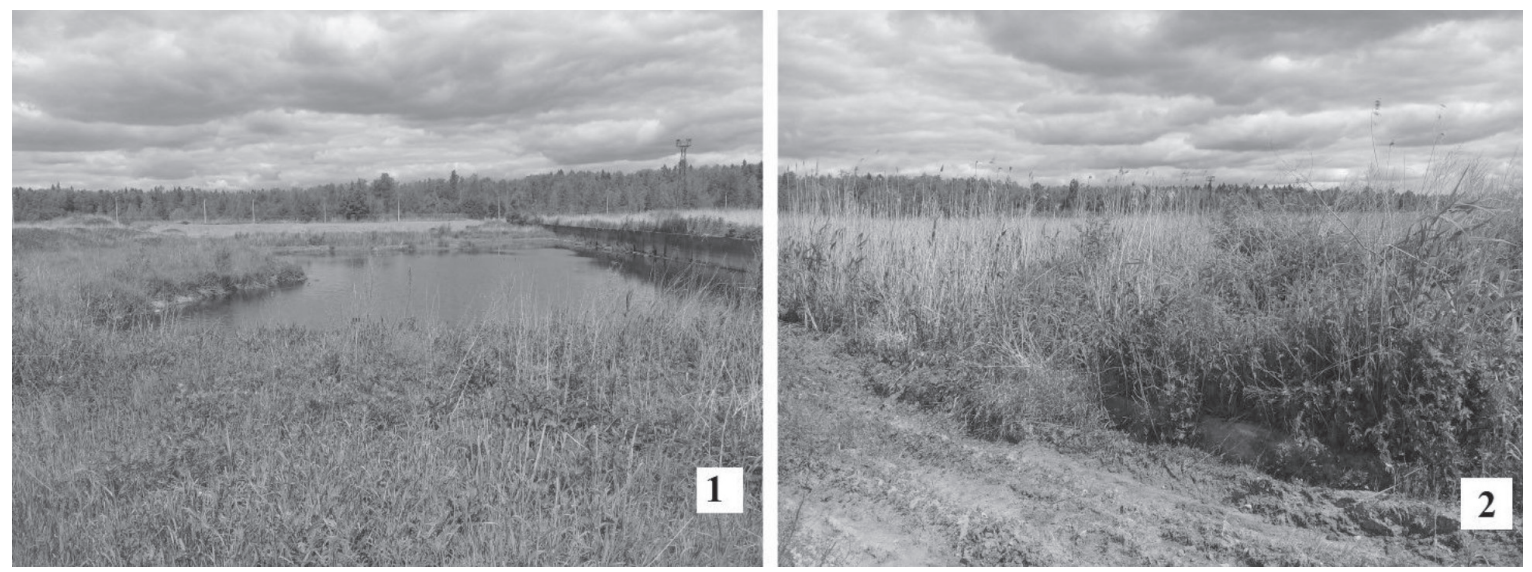

Fig. 5. Sludge tanks (drying beds) 1986-2003. 1) used for the placement of sediment (snow) and cards to host sediment; 2) ash from sewage sludge incineration was stored in this territory (highlighted in red), the content of mobile forms of heavy metals in the ash from sewage sludge incineration is given in the Table 2.

Table 2. Comparative characteristics of the total concentration of heavy metalls and mobile forms of heavy metalls in the ash from the sewage sludge incineration.

\begin{tabular}{|c|c|c|}
\hline \multirow{2}{*}{$\begin{array}{l}\text { Heavy } \\
\text { metals }\end{array}$} & \multicolumn{2}{|c|}{ Ash from the sewage sludge incineration } \\
\hline & $\begin{array}{l}\text { Total concentration, } \\
\mathrm{mg} / \mathrm{kg}\end{array}$ & $\begin{array}{l}\text { Labile forms } \\
\mathrm{mg} / \mathrm{kg}\end{array}$ \\
\hline $\mathrm{Cd}$ & 11 & 1.3 \\
\hline $\mathrm{Co}$ & 8.3 & 0.46 \\
\hline $\mathrm{Mn}$ & 1400 & 250 \\
\hline $\mathrm{Cu}$ & 640 & 76 \\
\hline $\mathrm{Ni}$ & 51 & 1.4 \\
\hline $\mathrm{Hg}$ & 0.05 & 0.05 \\
\hline $\mathrm{Cr}$ & 78 & 0.022 \\
\hline $\mathrm{Zn}$ & 850 & 54 \\
\hline
\end{tabular}

complex-forming ability to metal ions, which increases the stability of the resulting complexes [21-23], which is probably due to the high concentrations of heavy metals in the soil of the test site.

However, along with the complexing ability of heavy metals, soil alkalinity can cause increased solubility of arsenic [24] and its sorption with iron oxides [25]. The compounds of Fe may have high concentrations in sewage sludge due to the use of coagulants based on them, such as $\mathrm{Fe}_{2}\left(\mathrm{SO}_{4}\right)_{3}$. Studies of the landfill soil $\mathrm{pH}$ showed that the $\mathrm{pH}$ varied in the range of $6.7-8$, which corresponds to slightly alkaline soils typical of St. Petersburg and probably could have contributed to the migration of As in 2017 compared to 2011 (Fig. 4).

The latter probably causes long time cycles of metals absorption from soils by ground vegetation within the boundaries of the test site, which can lead to weakening of the soil's sanitary properties and high pathogenicity, shown in previous studies [26].

A comparative analysis of the heavy metals and arsenic content for sod-podzolic soils in the European part of Russia [27] showed a significant excess of heavy metal concentrations in the landfill soil (Table. 4) having the following maximum series: $\mathrm{Cd}_{1083,3}>\mathrm{Cu}_{45,3}>\mathrm{Pb}_{16}>\mathrm{Hg}_{15}>\mathrm{Zn}_{5,11}>\mathrm{Ni}_{4}>\mathrm{As}_{2,86}$.

The $\mathrm{CD}$ concentration ranged from 0.19-130 mg/kg; Cu 17-680 mg/kg; Pb 11-240; Zn $45-230 \mathrm{mg} / \mathrm{kg}$; $\mathrm{Hg}$ 0.05-1.5 mg/kg; Ni 6.9-120 mg/kg; As $1.4-\mathrm{mg} / \mathrm{kg}$. Such wide variations in heavy metal concentrations may be due to the fact that sewage collection in St. Petersburg has a mixed type of economic and industrial effluents. This may also be due

Table 3. Background contents of gross forms of heavy metals and arsenic in soils (mg/ kg) (Approximate values for the Central part of Russia).

\begin{tabular}{|c|c|c|c|c|c|c|c|c|}
\hline Soils & $\mathrm{Zn}$ & $\mathrm{Cd}$ & $\mathrm{Pb}$ & $\mathrm{Hg}$ & $\mathrm{Cu}$ & $\mathrm{Co}$ & $\mathrm{Ni}$ & $\mathrm{As}$ \\
\hline Sod-podzolic sandy and sandy loam & 28 & 0.05 & 6 & 0.05 & 8 & 3 & 6 & 1.5 \\
\hline Sod-podzolic loamy and clay-loam & 45 & 0.12 & 15 & 0.10 & 15 & 10 & 30 & 2.2 \\
\hline Grey forest & 60 & 0.20 & 16 & 0.15 & 18 & 12 & 35 & 2.6 \\
\hline Chernozems & 68 & 0.24 & 20 & 0.20 & 25 & 25 & 45 & 5.6 \\
\hline Chestnut soils & 54 & 0.16 & 16 & 0.15 & 20 & 12 & 35 & 5.2 \\
\hline Serozems & 58 & 0.25 & 18 & 0.12 & 18 & 12 & 40 & 4.5 \\
\hline
\end{tabular}


Table 4. The Ratio of heavy metal concentrations in soil of the testing ground to the approximate (background) values for the Central part of Russia*.

\begin{tabular}{|c|c|c|c|c|c|c|c|}
\hline Selection points & $\mathrm{Zn}$ & $\mathrm{Cd}$ & $\mathrm{Pb}$ & $\mathrm{Hg}$ & $\mathrm{Cu}$ & $\mathrm{Ni}$ & $\mathrm{As}$ \\
\hline 1 & $\mathbf{3 . 7}$ & $\mathbf{9 1}$ & $\mathbf{3}$ & $\mathbf{4 . 4}$ & $\mathbf{7}$ & 0.63 & 0.63 \\
\hline 2 & $\mathbf{1 . 9 7}$ & $\mathbf{5 . 4 1}$ & $\mathbf{1 . 6}$ & 0.5 & $\mathbf{4 , 2}$ & 0,97 & $\mathbf{1 , 1 8}$ \\
\hline 3 & 1 & $\mathbf{1 , 5 8}$ & $\mathbf{0 . 7 3}$ & 0.5 & $\mathbf{1 . 1 3}$ & 0.26 & $\mathbf{1 . 1}$ \\
\hline 4 & $\mathbf{1 . 4 7}$ & $\mathbf{1 8 . 3 3}$ & $\mathbf{1 . 3 3}$ & 0.5 & $\mathbf{1 . 9 3}$ & 0.23 & 0.73 \\
\hline 5 & $\mathbf{2 . 6 7}$ & $\mathbf{1 1 7}$ & $\mathbf{2 . 6 7}$ & $\mathbf{2}$ & $\mathbf{5 . 7}$ & 0.93 & 0.72 \\
\hline 6 & $\mathbf{2 . 4 4}$ & $\mathbf{4 6 6}$ & $\mathbf{9 . 3 3}$ & $\mathbf{1 . 1}$ & $\mathbf{3 1 . 3}$ & 0.7 & $\mathbf{2 . 8 6}$ \\
\hline 7 & $\mathbf{5 . 1 1}$ & $\mathbf{5 4 . 1}$ & $\mathbf{1 . 6 6}$ & 1 & $\mathbf{6 . 6 6}$ & 0.66 & $\mathbf{1 . 2 7}$ \\
\hline 8 & $\mathbf{4 . 6 7}$ & $\mathbf{1 4 1 . 6}$ & $\mathbf{2 . 6}$ & $\mathbf{2}$ & $\mathbf{8 . 7 2}$ & 0.83 & 0.77 \\
\hline 9 & $\mathbf{1 . 6 9}$ & $\mathbf{1 0 8 3 . 3}$ & $\mathbf{1 6}$ & $\mathbf{1 5}$ & $\mathbf{4 5 . 3}$ & $\mathbf{4}$ & $\mathbf{1 . 8 1}$ \\
\hline
\end{tabular}

*Excess of the concentrations (in number of times) is highlighted in bold.

Table 5. Criteria for assessing the degree of soil contamination with inorganic substances.

\begin{tabular}{|c|c|c|c|}
\hline Content in soil, $\mathrm{mg} / \mathrm{kg}$ & \multicolumn{3}{|c|}{ Hazard class of compound } \\
\hline & 1 & 2 & 3 \\
\hline$>\mathrm{K}_{\max }$ & Very strong & Very strong & Strong \\
\hline From MPC to max concentration $_{\text {From 2 background values to MPC }}$ & Very strong & Strong & Average \\
\hline
\end{tabular}

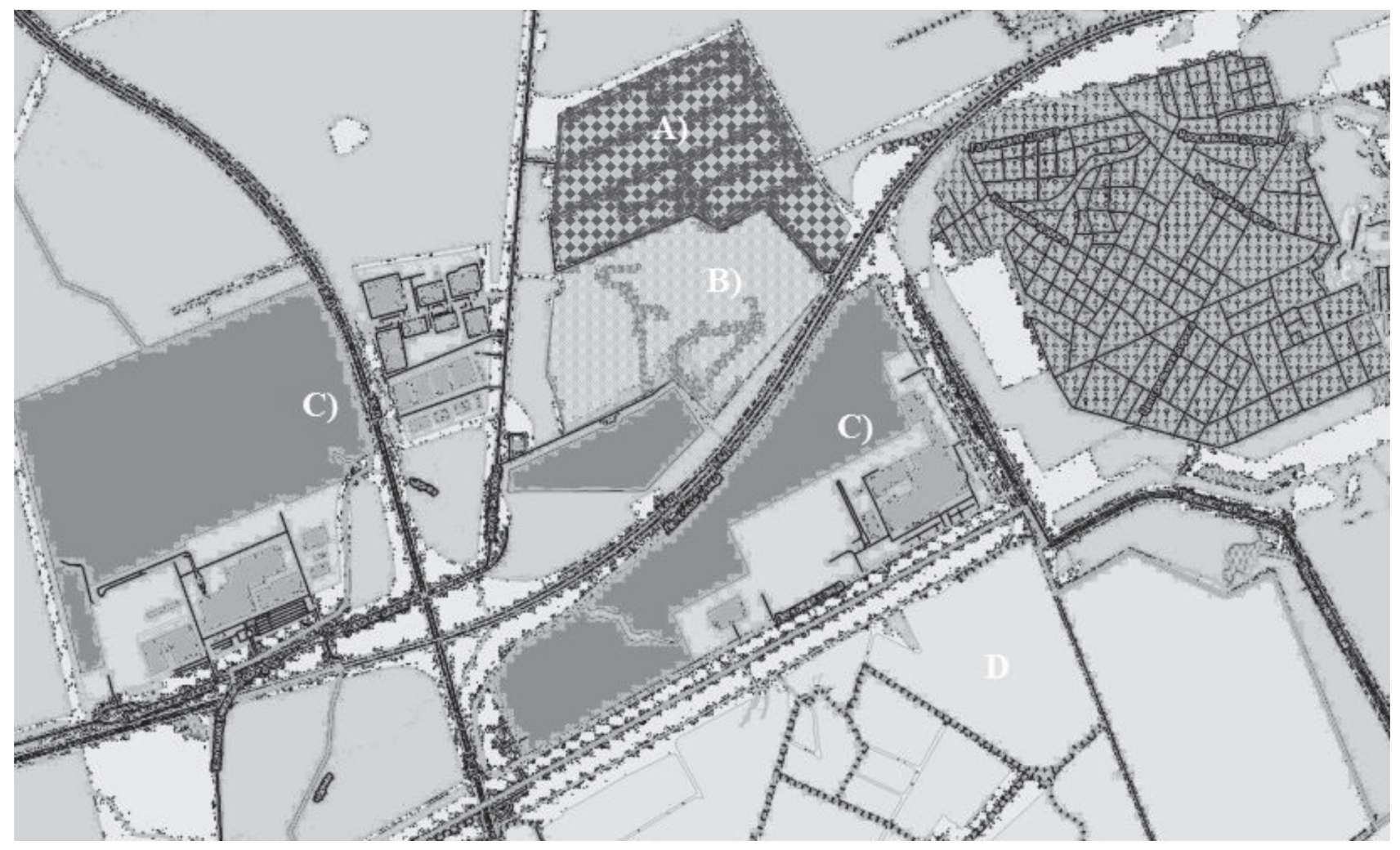

Fig. 6. The prospect of development of territories in the area of Sewage sludge and Municipal waste landfills locations. A) Sewage sludge landfill; B) Municipal waste landfill; C) Territories for new construction (industrial zone); D) Territories for residential buildings and recreational areas. 
to the fact that many businesses located in the city do not have local cleaning.

This is consistent with studies [28], showing that 10-20-year old sewage sludge disposed of at the landfill exceeded the standard concentrations for heavy metals $(\mathrm{Cd}, \mathrm{Zn}, \mathrm{Cr}, \mathrm{Cu})$.

For comparison, in Shanxi province [29] heavy metals were ranked in the following order: $\mathrm{Cd}>\mathrm{Zn}>\mathrm{Cu}>$ $\mathrm{As}>\mathrm{Cr}>\mathrm{Ni}>\mathrm{Pb}$. For almost all stations, $\mathrm{Cu}, \mathrm{Zn}$, and $\mathrm{Cd}$ were dominant in terms of environmental hazard. The concentrations of As were within the acceptable range.

At sewage facilities in Limpopo province in South Africa, $\mathrm{Zn}$ and $\mathrm{Cu}$ concentrations were significantly higher than normal [30]. In studies, it has been shown [31] that $\mathrm{Cd}$ concentrations vary widely, while $\mathrm{Zn}$ concentrations vary slightly (the range of concentrations was almost always stable). Along with our research, this indicates that $\mathrm{Cd}$ to be the most dynamic metal in sewage sludge.

Basically, the soils of the test site have a very high contamination degree (Table 5). This causes the entry of heavy metals into the deeper layers of soil, ground water, and at the same time contributes to the accumulation of heavy metals by ground vegetation (Phrágmites austrális, Liriodendron tulipifera, Betula schmidtii, Quercus acutissima) [32], while the bulk of heavy metals (especially zinc, etc.) were stopped in the green part of plants.

According to the data [33], high concentrations of zinc did not lead to negative consequences, according to other data [34] concentrations of zinc $100-400 \mathrm{mg} / \mathrm{kg}$ of dry weight cause toxicity in mature leaf tissues and can lead to chlorosis, especially in young leaves, growth retardation, and the appearance of necrotic tissues.

The special nature of the problem of soil contamination with heavy metals and arsenic from the "Severny" landfill is that the landfill is located in the catchment area of the Eastern part of the Gulf of Finland and borders several projected sites of "Sestroretskoye boloto", the "Yuntolovsky" reserve, the "Novoorlovsky" reserve, and the "Petrovsky prund" natural monument (Fig. 6). It is obvious that the presence of high concentrations of heavy metals and arsenic does not contribute to the use of these territories for residential or recreational purposes.

In accordance with the General plan of St. Petersburg [36] 2025 the establishment of a specially protected natural reserve "Levashovo forest" on the territory of "Kurortny" and "Vyborgsky" districts of St. Petersburg are envisaged, which boundaries border to the landfill impact (Fig. 7).

It remains unclear how and when the landfill reclamation works will be carried out, and what social function these territories will acquire. And at the same time, such changes to the law "On the General plan of St. Petersburg [35] "will migrate" from one version to another", but the problem remains unchanged. The environmental and socio-economic consequences of eliminating objects of environmental damage will have increasingly vague prospects year on year.

The fact that to date the strategic administrative management is dominated not by a target, but by a normative and instructive approach restricting the field of decision-making, i.e. non-trivial "pre-prescribed"

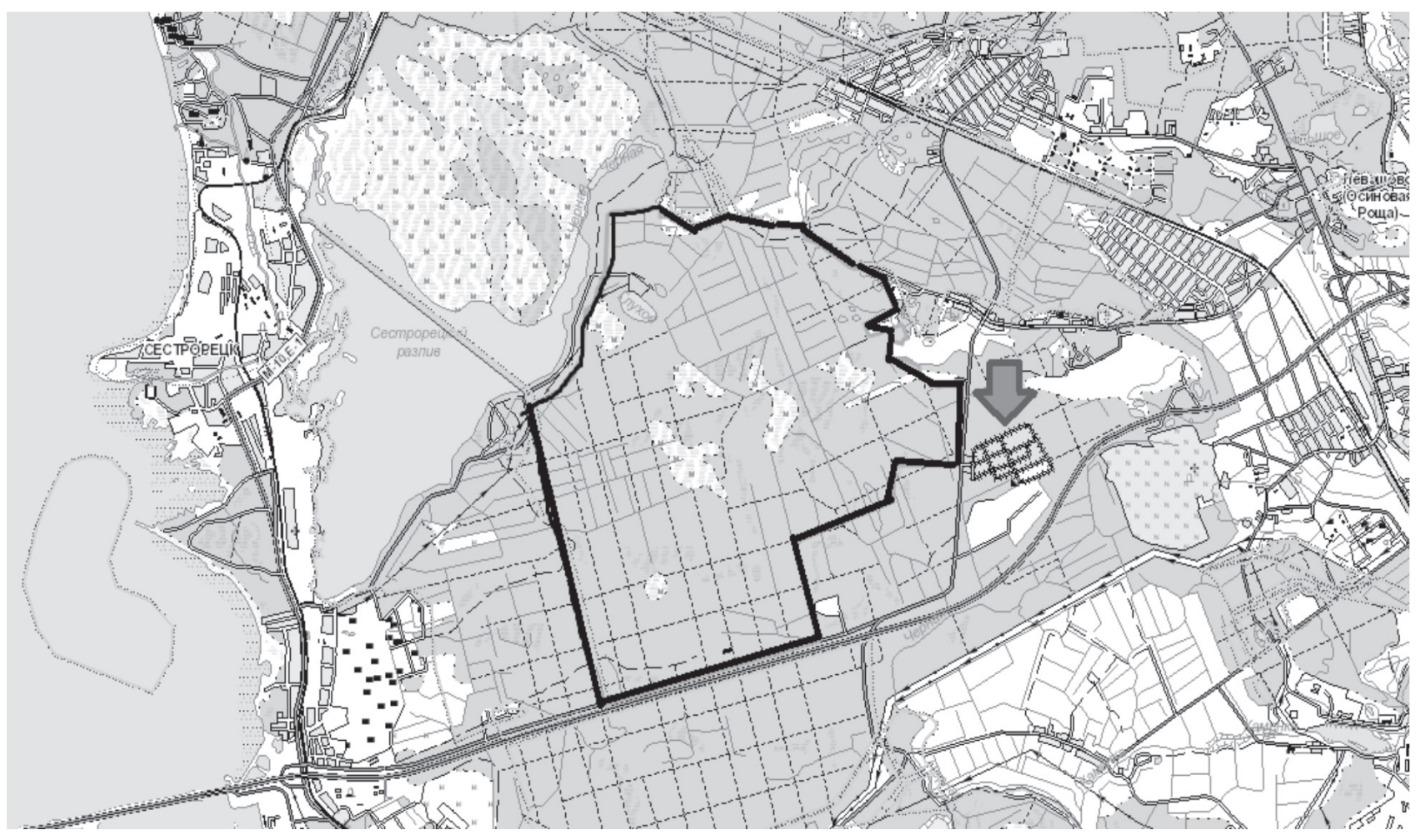

Fig. 7. Borders (-) of the projected specially protected natural areas "LevashovskyForest " $\downarrow$ - place of the landfill. 
approaches, and also takes into account rapidly changing socio-economic, political and other trends that are not always justified is considered as the reason for this $[36,37]$.

\section{Conclusions}

The study showed that over the period from 2011 to 2017, the sewage sludge disposal increased soil contamination with heavy metals at the landfill. The dynamics of soil contamination with arsenic remained stable and exceeded both the standard national LOC indicators and background concentrations in sodpodzolic soils in the European part of Russia. The most polluted areas of the landfill, in which drying beds were previously located, are the areas where the anti-filtration system as a solid concrete coating was organized. A significant increase in $\mathrm{Cd}, \mathrm{Cu}, \mathrm{Ni}, \mathrm{Pb}$, and $\mathrm{Zn}$ was observed at all sampling points. Significant concentrations of labile forms of heavy metals from ash (from incineration of sewage sludge) cause their migration to the soil, but probably to a lesser extent than from sewage sludge disposed of at the landfill by using other treatment methods. This indicates that the deposition of sewage sludge in the same landfill by various methods (even those recognized as safer, such as geotubing, utilization of slag from incineration of sewage sludge) causes soil contamination in one way or another and should be studied more carefully. Therefore, further studies are planned in order to identify the migration of heavy metals from landfill soils to underground water, to develop measures for the territory reclamation, and to prevent diseases of the population. This can give a more complete picture of the negative impact of these objects types and the conditions of their geographical location.

\section{Acknowledgements}

The article was prepared in the framework of research "Systematization, identification and methods of assessment of objects of past environmental damage", state registration number 0241-2014-0006.

\section{Conflict of Interest}

The authors declare no conflict of interest.

\section{References}

1. MORKUNAS I., WOŹNIAK A., MAI V.C., RUCIŃSKA-SOBKOWIAK R., JEANDET P. The Role of Heavy Metals in Plant Response to Biotic Stress. Molecules (Basel, Switzerland), 23 (9), 2320, 2018
2. TCHOUNWOU P.B., YEDJOU C.G., PATLOLLA A.K., SUTTON D.J. Heavy metal toxicity and the environment. Experientia supplementum, 101, 138, 2012.

3. NOVIKOV S.G. Radial distribution of gross content and mobile forms of heavy metals in soils of Petrozavodsk on public lands. 2, 5. 2014.

4. ABOYEJI O.S., EIGBOKHAN S.F. Evaluations of groundwater contamination by leachates around Olusosun open dumpsite in Lagos metropolis, southwest Nigeria. Journal of Environmental Management. 183, 338, 2016.

5. CHENG L., WANG L., GENG YU., WANG N., MAO YU., CAI YO. Occurrence, speciation and fate of mercury in the sewage sludge of China. Ecotoxicology and Environmental Safety. 186, 2019.

6. DREGULO A.M., PITULKO V.M., RODIONOV V.Z., KULIBABA V.V., PTUKHOV V.V. Geoecological evaluation of environmental damage to the results of longterm dynamics of benzopyrene and petroleum within landfill sludge. IOP Conf. Ser.: Earth Environ. Sci. 321, 012037, 2019.

7. DREGULO A.M., KUDRYAVTSEV A.V. Transformation of techno-natural systems of water treatment to objects of past environmental damage: peculiarities of the legal and regulatory framework. Water and Ecology. 3 (75), 58, 2018.

8. AISAEV A.A., ALEKSEEV M.I., ANDREEV S.A. Discharge and treatment of waste waters of St. Petersburg. 418, 1999.

9. ROSINSKA A. Ortho-PCBs in sewage sludge during methane fermentation Inżynieria// Ekologiczna. 25, 139, 2011.

10. COLLIVIGNARELli M.C., ABBÀ A., FRATTAROLA A., MIINO M.C., PADOVANI S., KATSOYIANNIS I., TORRETTA V. Legislation for the reuse of biosolids on agricultural land in Europe: overview Sustain. 11, 6015, 2019.

11. MOSKVICHEVA A.V., DOSKINA E.P., MOSKVICHEVA E.V. Sewage sludge or waste? Questions of legal regulation. Water supply and sanitary equipment. 4, 20, 2016.

12. Meeting of the Committee of the Federation Council on agrarian and food policy and environmental management «on practical aspects of utilization of treated sewage sludge». Moscow. 2012.

13. MAKHNENKO E.P. Sewage sludge and other nontraditional organic fertilizers. Textbook. Moscow. 15. 2012.

14. KAPELKINA L.P. Problems of rationing of polluting substances in soil//Ecological regulation and control of the quality of the soil and land. Collective monograph. 201, 2013.

15. RUBLEVSKAYA O.N., KRASNOPEEV A.L. Experience in introduction of up-to-date technologies and methods of wastewater sludge treatment.Water supply and sanitary technique 4, 66, 2011.

16. SKOWROŃSKAA M., BIELIŃSKA E., SZYMAŃSKI K., FUTA B., ANTONKIEWICZ J., KOŁODZIEJE B. An integrated assessment of the long-term impact of municipal sewage sludge on the chemical and biological properties of soil. CATENA 189, 2020.

17. MEDVEDEV I.F., DEREVYAGIN S.S. Heavy metals in ecosystems. 144. 2017.

18. LIU Q., WANG Z.J., TANG H.X. Research progress in heavy metals speciation and toxicity and bioavailability of heavy metals. Chin. J. Environ. Sci. 17, 91, 1996.

19. SKARPA P., POSPISILOVA L., BJELKOVA M., FIALA K., HLUSEK J. Effect of organic matter and $\mathrm{pH}$ on the mobility of some heavy metals in soils of 
permanent grasslands in the foothills of the Hruby Jesenik Mts. Ecological Chemistry and Engineering 18, 1348, 2011.

20. DONG B., LIU X.G., DAI, L.L., DAI X.H. Changes of heavy metal speciation during high-solid anaerobic digestion of sewage sludge. Bioresource Technology 131, 153, 2013.

21. JIN L.Y., ZHANG G., TIAN H. Current state of sewage treatment in China. Water Resource 66, 86, 2014.

22. ZORPAS A.A., LOIZIDOU M. Sawdust and natural zeolite as a bulking agent for improving quality of a composting product from anaerobically stabilized sewage sludge. Bioresour. Technol. 99 (66), 7546, 2008.

23. WANG L.M., ZHANG, Y.M., LIAN, J.J., CHAO, J.Y., GAO Y.X., YANG F., ZHANG L.Y. Impact of fly ash and phosphatic rock on metal stabilization and bioavailability during sewage sludge vermicomposting. Journal of Hazardous Materials 136, 282, 2013.

24. KARCZEWSKA A., BOGDA A., KRYSIAK A. Arsenic in soils in the areas of former arsenic mining and processing in Lower Silesia, SW Poland P. Bhattacharya, A.B. Mukherjee, R.H. Loeppert (Eds.), Arsenic in Soil and Groundwater Environments: Biogeochemical Interactions, Elsevier Book Series: Trace Metals and Other Contaminants in the Environment. 9, 412, 2007.

25. LEWIŃSK K., KARCZEWSKA A., SIEPAK M., GAŁKAB B. Potential of Fe-Mn wastes produced by a water treatment plant for arsenic immobilization in contaminated soils/ Journal of Geochemical Exploration. 84, 227, 2018.

26. DREGULO A.M., VITKOVSKAYA R.F. Microbiological evaluation of soils of sites with accumulated ecological damage (Sewage Dumps). Fiber Chemistry. 50 (3), 245, 2018.

27. CODE OF PRACTICE 11-102-97. Engineering environmental site investigations for construction. 23, 1997.

28. TUTUNIKOVA M.V. Study of the behavior of heavy metals in agroecosystems at a soil path of recycling of deposits of sewage sludge sites OSK. Kaluga. 10, 2007.
29. XU J.Q., YU R.L., DONG X.Y., HU G.R., SHANG X.S., WANG Q., LI H.W. Effects of municipal sewage sludge stabilized by fly ash on the growth of Manilagrass and transfer of heavy metals. J. Hazard. Mater. 217, 62, 2012.

30. SHAMUYARIRA K.K, GUMBO J.R. Assessment of heavy metals in municipal sewage sludge: a case study of Limpopo province, South Africa. International journal of environmental research and public health. 11 (3), 2572, 2014.

31. ALYSSON ROBERTO BAIZI E SILVA, CAMILOTTI F. Risks of Heavy Metals Contamination of Soil-Pant System by Land Application of Sewage Sludge: A Review with Data from Brazil. Environmental Risk Assessment of Soil Contamination. 5, 2017.

32. WEI Y., LIU Y. Effects sewage sludge compost application on crops and cropland in a 3-year study. Chemosphere. 59, 1259, 2005

33. CASADO-VELA J., SELLES S., DIAZ-CRESPO C., NAVARRO-PEDRENO J., MATIAX-BENEYTO J., GOMEZ I. Effect of composted sewage sludge application to soil on sweet pepper crop (Capsicum annuum var. annuum) grow under two explotitation regimes. Waste Manage 27, 1510, 2007.

34. CHIU K.K., YE Z.N., WONG M.N. Growth of Vetiveria zizanionides and Phragmities austails on $\mathrm{Pb} / \mathrm{Zn}$ and $\mathrm{Cu}$ mine tailings amended with manure compost and sewage sludge: a greenhouse study. Bioresource Technology 97, $158,2006$.

35. Law of Saint Petersburg "on the General plan of Saint Petersburg". Saint-Petersburg. 26. 2010.

36. MCGRANAHAN G., MARCOTULLIO P.J., BAI X, BALK D., BRAGA T., DOUGLAS I., EMQVIST T., REES W., SATTERTHWAITE D., SONGSORE J., ZLOTNIK H. Chapter 27: Urban systems. Current Status and Trends: Finding of the condition and trends working group. Ecosystems and human well-being. Washington, DC: Island; 1, 796, 2005.

37. PETROV M.V., ROZHKOVA E.S. Interrelation of documents of strategic planning of territorial development / territorial planning: new functions, experience, problems, solutions: Collected monograph. 51, 2009. 